\title{
Hubungan Bahasa, Semiotika Dan Pikiran Dalam Berkomunikasi
}

\author{
M. Hasbullah
}

Sekolah Tinggi Ilmu Bahasa Arab (STIBA) Darul Ulum Banyuanyar Pamekasan rasenshrkn@gmail.com

\begin{abstract}
Abstrak
Bahasa merupakan alat komunikasi oleh sekelompok manusia untuk melahirkan perasaan dan pemikiran. Sejak jaman purba manusia sudah tertarik untuk menyelidiki seluk beluk bahasa. Penelitian ini bertujuan untuk mengungkap asal mula perkembangan bahasa dan merefleksikan hubungannya dengan semiotika dan pikiran. Hasil dari penelitiam ini menyimpulkan bahwa Bahasa, semiotika dan pikiran memiliki keterkaitan yang saling mempengaruhi (resiprokal). Dalam wacana lingguistik, bahasa diberi pengertian sebagai sistem simbol bunyi yang bermakna dan berartikulasi, yang dipakai sebagai alat komunikasi, sedangkan dalam pengertian metaforis, istilah bahasa mengacu pada berbagai cara komunikasi atau berkontak (isyarat atau simbol lainnya). Adapun semiotika mempelajari sistem-sistem, aturan-aturan, yang memungkinkan tanda-tanda tersebut mempunyai arti. Sedangkan pikiran akan membuat enkode semantic dan encode gramatikal didalam otak pembicara, dilanjutkan dengan membuat encode fonologi. Kemudian di lanjutkan dengan penyusunan decode fonologi, decode gramatikal, dan decide semantic pada pihak pendengar yang terjadi di dalam otaknya sehingga komunikasi kedua belah pihak antara pembicara dan pendengar dapat saling mengerti dan memahami.

Kata kunci: Bahasa, Semiotika dan Pikiran.
\end{abstract}




\section{Pendahuluan}

Bahasa sebagai sarana komunikasi dalam kehidupan kita sehari-hari sangatlah menentukan keberlangsungan hidup kita. Semakin banyak seseorang menguasai bahasa, maka semakin mudahlah mereka berinteraksi dengan seseorang. Bahasa merupakan alat komunikasi oleh sekelompok manusia untuk melahirkan perasaan dan pemikiran. Pendukung aliran teologis mengatakan, manusia bisa berbahasa karena anugerah tuhan, pada mulanya Tuhan mengajarkan kepada Adam selaku nenek moyang seluruh manusia. Adapun menurut naturalis, kemampuan manusia berbahasa merupakan bawaan alam, sebagaimana kemampuan melihat, mendengar maupun berjalan. Sedangkan para konvensionalis, berpandangan bahwa bahasa pada awalnya muncul sebagai produk sosial. Menurut konvensialis bahasa merupakan hasil konvensi yang disepakati dan kemudian dilestarikan oleh masyarakat. Dari catatan sejarah terdapat bukti sejak jaman purba manusia sudah tertarik untuk menyelidiki seluk beluk bahasa. ${ }^{1}$ Penelitian ini bertujuan untuk mengungkap asal mula perkembangan bahasa dan merefleksikan relasinya dengan semiotika dan pikiran.

\section{Asal Mula Bahasa}

Para ahli bahasa dan orang-orang dari bidang ilmu lainnya berspekulasi tentang asal mula bahasa. Memang teka-teki tentang asal mula bahasa itu menjadi kajian menarik bagi mereka yang menyukai materi. Sebagian dari peneliti mungkin berasumsi bahasa apakah yang digunakan oleh Adam dan Hawa. Para pakar bahasa menjelaskan bahwa kitab Taurat dan Injil pertama kali ditulis dalam Bahasa Ibrani. Akan tetapi, kitab-kitab suci tersebut hadir di dunia sudah sekian ribu tahun setelah munculnya manusia di bumi

${ }^{1}$ Ruhlen, On the Origin of Langguage Studies in Lingguistic Taxonomy, dikutip dari Abd Ghafur, Okara, jurnal bahasa dan sastra. (pamekasan: pusat bahasa STAIN ), Vol.ii, Nopember 2009. Hlm, 136. 
(berdasarkan pada pandangan antropolog). ${ }^{2}$ Kisah dalam 'kejadian' tentunya mengacu ke periode yang lebih primitif daripada periode keluarnya kedua kitab suci itu.

Ilmuan barat banyak yang percaya, bahwa sampai saat ini bahasa Ibrani disamping bahasa pertama manusia juga merupakan asal mula bahasa lainnya. namun tidak ada alasan untuk berpikir bahwa bahasa Ibrani menyerupai bahasa pertama manusia. Hal itu dapat dibuktikan dengan prinsip-prinsip ilmu linguistik bahwa kebanyakan bahasa manusia tidak berasal dari bahasa Ibrani. Demikian pula, banyak pembaca injil behwa kitab tersebut tidak menyebutkan seecara spesifik bahasa yang dipakai Adam dan Hawa.

Pada akhir abad ke-17, seorang filolog Swedia menyatakan bahwa di Taman Eden atau Surga Firdaus Tuhan berbahasa Swedia, Adam berbahasa Denmark, dan si pembantu berbahasa Perancis. Namun pernyataan filolog tersebut disanggah menurut 'kejadian' hanya satu bahasa yang dipakai oleh manusia sebelum tuhan membuat mereka mampu berbicara berbagai bahasa. ${ }^{3}$

\section{Teori-teori Asal Mula Bahasa}

Apabila kita menelusuri jejak kehidupan nenek moyang manusia di muka bumi sejak lima ratus ribu tahun yang silam, kita tidak pernah menemukan bukti-bukti langsung mengenai bahasa nenek moyang kita tersebut. Banyak teori yang berusaha menjelaskan bagaimana asal mula bahasa manusia. Teori tersebut bersumber dari Tuhan, bunyi alam, isyarat lisan, dan teori yang mendasarkan pada kemampuan manusia secara fisiologis.

Komaruddin menjelaskan bahwa secara garis besar terdapat tiga teori mengenai asal-usul bahasa, yaitu; teologis, naturalis dan konvensionalis. ${ }^{4}$ Pendukung aliran teologis mengatakan, manusia bisa berbahasa karena anugerah tuhan, pada mulanya Tuhan mengajarkan kepada Adam selaku

\footnotetext{
hlm. 276.

2 Duranti, Lingguistic Antropology (Cambridge: Cambridge University Press, 1977),

${ }^{3}$ Abd Ghafur, Okara, jurnal bahasa dan sastra. (pamekasan: pusat bahasa STAIN ), Vol.ii. Tahun 4, Nopember 2009. Hlm, 138.

${ }^{4}$ Komaruddin Hidayat, Memahami Bahasa Agama, (jakarta: Paramadina 1996), hlm. 29.
} 
nenek moyang seluruh manusia. Hal ini sesuai dengan data kitab suci; seperti dalam Agama Islam, Allah SWT, mengajarkan kepada Nabi Adam nama-nama benda (Q.S. Al-Baqarah : 31) " dan dia mengajarkan kepada Adam nama-nama (benda) seluruhnya, kemudian mengemukakannya kepada para malaikat lalu berfirman: sebutkanlah kepada-Ku nama benda-benda itu jika kamu benar orang-orang yang benar ". juga (Q.S. Ar-Rum : 22) " dan diantara tanda-tanda kebesarann-Nya ialah menciptakan langit dan bumi dan berlainan bahasamu dan warna kulitmu. Sesungguhnya pada demikian itu benar-benar terdapat tanda-tanda bagi orang-orang yang mengetahui".

Apabila kita melihat agama Hindu, bahasa diciptakan oleh Dewi Saraswati, istri dari dewa Brahma, sang pencipta alam. Menurut kisah dalam 'kejadian', manusia diciptakan dari imajinasi Tuhan dan kemampuan bahasa merupakan salah satu dari sifat manusia. 'kejadian' mengabarkan, dari tanah tuhan menciptakan semua binatang di padang berantara, unggas di angkasa, dan membawa binatang dan unggas itu di hadapan Adam untuk melihat bagaimana adam memanggil makhluk-makhluk lainnya, dan apapun yang dipanggil Adam sejak saat itulah binatang-binatang itu mempunyai nama. Menurut kebanyakan agama, tampak bahwa tuhan melengkapi penciptaan manusia dengan bahasa, akan tetapi, kisah dalam agama-agama itu belum dapat membantu kita bagaimana manusia dapat memulai berbicara dan bahasa apa yang ia gunakan. ${ }^{5}$

Teori kedua, naturalis, kemampuan manusia berbahasa merupakan bawaan alam, sebagaimana kemampuan melihat, mendengar maupun berjalan. Menurut Red west ada cerita dari Mesir, bahwa sekitar abad ke-17 SM Raja Mesir Psametichus mengadakan eksperimen terhadap bayi yang dibesarkan di hutan belantara dengan pola pengasuhan yang tanpa bersentuhan dengan pemakaian bahasa apapun. Setelah berusia dua tahun, bayi tersebut dilaporkan oleh pengasuh suruhan istana dapat mengucapkan kata pertamanya "becos" yang berarti "roti", dalam bahasa Phrygia (bahasa Mesir kuno). Dan cerita ini,

${ }^{5}$ Abd Ghafur, Okara, jurnal bahasa dan sastra ... hlm, 138-139. 
banyak orang Mesir yang mempercayai bahwa bahasa Mesirlah yang merupakan bahasa yang pertama dikuasai manusia, sekaligus diklaim sebagai bahasa yang pertama kali ada di muka bumi. Teori serupa, yaitu naturalis, diperkenalkan oleh Max muller, yang kemudian populer dengan sebutan dingdong theory, yang berpandangan bahwa pada awalnya bahasa mucul secara alamiah, muncul secara spontan ketika manusia berinteraksi dengan lingkungannya, terutama ketika mendengar suara-suara alam. Dikatakan teori ding-dong karena getaran suara yang ditangkap oleh indera telinga bagaikan pukulan pada bel sehingga melahirkan bunyi yang diteruskan oleh mulut. 6

Dan teori ketiga, konvensionalis, berpandangan bahwa bahasa pada awalnya muncul sebagai produk sosial. Ia merupakan hasil konvensi yang disepakati dan kemudian dilestarikan oleh masyarakat. Salah satu bentuk konvensi yang terkenal adalah yo-he-ho theory. Pandangan ini mendasarkan pada argumen dan pengamatan empiris bahwa bahasa konvensi muncul dari suatu peristiwa sosial ketika masyarakat primitif melakukan kerja gotong royong. Misalnya, ketika beramai-ramai mearik pohon besar atau bersiap melawan serangan musuh. Pada saat itulah muncul ungkapan bahasa yang ekpresif dan berfungsi menyamakan langkah. ${ }^{7}$

Ada juga teori "bow-wow" yang mengatakan bahwa bahasa muncul sebagai tiruan bunyi-bunyi yang terdengar di alam, seperti nyanyian burung, suara binatang, suara guruh, hujan, angin, ombak sungai, samudra dan sebagainya, sehingga teori ini disebut echoic theory. Jadi tidak berevolusi sebagaimana aliran teori Darwinian di atas. Menurut teori "bow-wow" ada relasi yang jelas antara suara dan makna, sehingga bahasa tidak bersifat arbitrer. Misalnya, dalam bahasa Indonesia ada kata-kata seperti: menggelegar, bergetar, mendesis, merintih, meraung, berkokok dan sebagainya. Contoh lainnya, misalnya, oleh sebagian masyarakat anjing disebut sebagai "bow-wow" karena

${ }^{6}$ Komaruddin Hidayat, Memahami Bahasa Agama ..., hlm. 30.

${ }^{7}$ Komaruddin Hidayat, Memahami Bahasa Agama ..., hlm. 31. 
ketika menyalak suaranya terdengar "bow-wow". Dengan berpikir praktis, orang menamai binatang yang menyalak itu sebagai "bow-wow".

Ada juga teori "pooh-pooh" yang mengatakan pada awalnya bahasa merupakan ungkapan seruan keheranan, ketakutan, kesenangan, kesakitan dan sebagainya. Ada teori "yo-he-ho" yang mengatakan bahasa pertama timbul dalam suasana kegiatan sosial di mana terjadi deram dan gerak jasmani yang secara spontan diikuti dengan munculnya bahasa. Misalnya, ketika sekelompok orang secara bersama-sama mengangkat kayu atau benda berat, secara spontan mereka akan mengucapkan kata-kata tertentu karena terdorong gerakan otot. ${ }^{8}$

Pertentangan mengenai asal-usul bahasa jauh sebelum pemikir muslim telah muncul dan menjadi polemik di kalangan filosof Yunani. Apakah bahasa itu dikuasai alam, nature atau fisei, ataukah bahasa itu bersifat konvensi atau nomos. Pendapat yang menyatakan bahwa bahasa bersifat alamiah (fisei) yaitu bahasa mempunyai hubungan dengan asal-usul, sumber dalam prinsip-prinsip abadi dan tak dapatdiganti di luar manusia itu sendiri, dan karena itu tak dapat ditolak. Kaum naturalis dengan tokoh-tokohnya seperti Cratylus dalam dialog dengan Plato mengatakan bahwa senua kata pada umumnya mendekati benda yang ditunjuk. Jadi ada hubungan antara komposisi bunyi dengan apa yang dimaksud. Bahasa bukanlah yang hanya bersifat fisis belaka, melainkan talah mencapai makna secara alamiah, atau fisei. Sebaliknya, kaum konvensionalis berpendapat bahwa makna bahasa diperoleh dari hasil-hasil tradisi, kebiasaan berupa persetujuan bersama. Karena itu, bahasa dapat berubah dapat berubah dalam perjalanan zaman. Bahasa bukanlah pemberian tuhan, melainkan bersifat konvensional. Demikian pendapat Hermogenes saat berdialog dengan plato. ${ }^{9}$

Pandangan lain mengenai asal mula bahasa manusia didasarkan pada konsep bunyi alam. Pandangan itu sudah dikemukakan oleh filsuf Yunani Kuno. Socrates menyatakan teorinya tentang asal mula bahasa dalam Cratylus

\footnotetext{
8 https://uin-malang.ac.id/r/150301/spekulasi-tentang-asal-usul-bahasa.html

${ }_{9}$ Akhmad Muzakki, Kontribusi Semiotika dalam Memahami Bahasa Agama, (Malang: UIN Malang Press, 2007), hlm. 55-56.
} 
Plato. Dalam dialog tersebut, Socrates mencatat bahwa dalam bahasa Yunani, bunyai $\mathrm{r}$ sering hilang dalam kata-kata yang mempunyai arti gerak dan bunyi I sering mengacu pada kelancaran. Dia menyimpulkan onomatope, atau peniruan bunyi-bunyi tindakan, merupakan dasar asal mula bahasa dan merupakan alasan mengapa 'yang benar' dapat ditemukan untuk benda-benda yang menghasilkan bunyi-bunyi. ${ }^{10}$

Hingga abad ke 18 dan masa pencerahan (sebuah gerakan intelektual Eropa), sebagian besar pemikiran mengenai asal-usul bahasa berasumsi bahwa bahasa dimulai sejak adam dan hawa di Taman Firdaus. Teori terbaru mengenai asal usul bahasa adalah bahwa gerakan-gerakan tangan sederhana digunakan sejak 6 atau 7 juta tahun yang lalu, tak lama setelah garis keturunan (evolusi) manusia terpisah dengan kera. Teriakan digunakan untuk seruan ketakutan atau ledakan emosi. Sekitar 5 juta tahun yang lalu, Hominid awal yang dikenal sebagai Australopithecus mulai berjalan tegak, dan sebuah bentuk gerakan tangan yang lebih rumit mungkin digunakan sejak itu. kemudian 2 juta tahun yang lalu, ukuran otak bertambah dan gerakan tangan digunakan dalam berbagai kombinasi untuk mengekspresikan gagasan, dan tetap menjadi cara komunikasi yang utama.

Sekitar 100.000 tahun yang lalu, homo sapiens mungkin telah mengubah cara komunikasi utama dari gerakan tangan dan muka menjadi vokalisasi dan penggunaan suara-suara yang berbeda untuk menyampaikan berbagai makna. Lambat laun, gerakan isyarat berkurang meskipun kita masih menggunakannya sekarang untuk menegaskan pembicaraan, bahkan saat kita melakukan komunikasi melalui telepon ketika orang yang kita ajak bicara diujung sana tidak bisa melihat gerakan kita.

Bahasa lisan paling tua hampir bisa dipastikan adalah bahasa Maya yang telah ada sejak tujuh ribu tahun yang lalu ketika suku Maya bermigrasi ke selatan menuju Meksiko. Ada 30 bahasa Maya sebagai bahasa lisan sekarang

10 Pei, The History of langguage, Alih Bahasa; Nugroho Notosusanto, (Jakarta: Bratara 1965), hlm, 64. 
ini, masing-masing begitu dekat hubungannya sehingga para ahli bahasa percaya seluruh bahasa itu berasal dari satu bahasa proto-Maya.

Sedangkan bahasa tulisan pertama dikembangkan oleh bangsa Sumeria sejak lebih dari lima ribu tahun yang lalu. Bahasa tulisan pertama saat itu adalah "Cuneiform". Hurufnya berbentuk paku yang aneh dan itu merupakan pengembngan piktogram-piktogram yang lebih awal. Cuneiform adalah bahasa pertama yang bisa menyampaikan ide-ide dan suara-suara abstrak. Hanya ada 2 angka dalam cuneiform, bentuk paku vertikal atau angka satu dan bentuk paku horisontal untuk angka sepuluh. ${ }^{11}$

\section{Hubungan Bahasa, Semiotika, dan Pikiran}

\section{Bahasa Sebagai Tanda}

Dalam wacana lingguistik, bahasa diberi pengertian sebagai sistem simbol bunyi yang bermakna dan berartikulasi, yang bersifat arbitrer dan konvensional, yang dipakai sebagai alat komunikasi oleh sekelompok manusia untuk melahirkan perasaan dan pemikiran. Bahasa adalah kombinasi kata yang diatur secara sistemis, sehingga bisa digunakan seebagai alat komunikasi. Bahasa (kata) itu sendiri merupakan bagian integral dari simbol yang dipakai oleh kelompok masyarakatnya. Itu sebabnya, kata bersifat simbolis.

Istilah bahasa dapat digunakan dalam pengertian harfiah dan metaforis. Dalam pengertian harfiah, istilah bahasa mengacu pada bahasa biasa, yang alami, yang dipakai dalam keseharian. Sedangkan dalam pengertian metaforis, istilah bahasa mengacu pada berbagai cara komunikasi atau berkontak (isyarat atau simbol lainnya). dari dua istilah ini dapat dikatakan bahwa lingguistik berurusan dengan bahasa biasa, yang alami, yang dipakai dalam keseharian. ${ }^{12}$

Semiotika merupakan sebuah model ilmu pengetahuan sosial dalam memahami dunia sebagai sistem hubungan yang memiliki unit dasar yang

${ }^{11}$ Fachri, "Asal Usul Bahasa”, diakses dari

http:// fachri86.wordpress.com/2012/10/24/asal-usul-bahasa/ pada hari Rabu, 20 November 2019

${ }^{12}$ Alex Sobur, Analisis Teks Media: Suatu Pengantar Untuk Analisis Wacana, Analisis Semiotik, dan Analisis Framing, (Bandung: Rosda Karya, 2001), hlm. 42-43. 
disebut "tanda". Semiotika berasal dari kata Yunani, semeion yang berarti tanda. Tanda itu sendiri didenifisikan sebagai sesuatu yang dapat mewakili sesuatu yang lain atas dasar konvensi sosial. ${ }^{13}$

Istilah semiotika sering digunakan bersama istilah semiologi. Dalam kedua istilah ini tidak terdapat perbedaan yang subtantif, tergantung dimana istilah itu populer. Biasanya semiotika lebih mengarah pada tradisi Piercean, sementara istilah semiologi banyak digunakan oleh Saussure. Namun yang terakhir jika dibandingkan dengan yang pertama jarang dipakai. Ada kecendrungan, istilah semiotika lebih populer dari semiologi, sehingga para penganut madzhab Saussurean pun sering menggunakan istilah semiotika. Namun yang jelas, keduanya merupakan ilmu yang mempelajari hubungan antara signs (tanda-tanda) berdasarkan kode-kode tertentu. Tanda-tanda tersebut akan nampak pada komunikasi manusia lewat bahasa, baik lisan maupun isyarat. ${ }^{14}$

Jadi, semiotika adalah ilmu tentang tanda-tanda. Ilmu ini menganggap bahwa fenomena sosial atau masyarakat dan kebudayaannya merupakan tanda-tanda. Artinya, semiotika mempelajari sistem-sistem, aturan-aturan, yang memungkinkan tanda-tanda tersebut mempunyai arti. Dengan kata lain, semiotika mempelajari relasi diantara komponen-komponen tanda, serta relasi antara komponen-komponen terseebut dengan masyarakat penggunanya.

Umberto Eco menandaskan, bahwa ruang lingkup semiotika sangatlah luas sehingga menimbulkan kesan "imperialisme" yang arogan. Namun jika mengikuti Charles Morris, seorang filsung yang menaruh perhatian atas ilmu tanda-tanda, semiotika pada dasarnya dapat dibedakan ke dalam tiga cabang penyelidikan, yaitu sintaktika (sintaksis), semantika (semantik) dan pragmatika (pragmatik). hlm. 16.

${ }^{13}$ Umberto Eco, A Theory of Semiotics (Bloomington: Indiana university press, 1976),

${ }^{14}$ Akhmad Muzakki, Kontribusi Semiotika Dalam Memahami Bahasa Agama, (Malang: UIN-Malang Press, 2007), hlm. 9-10. 
Sintaktika adalah cabang penyelidikan semiotika yang mengkaji hubungan formal diantara satu tanda dengan tanda-tanda yang lain. Dengan kata lain, karena hubungannya formal ini merupakan kaidah-kaidah yang mengendalikan tuturan dan interpretasi, maka pengertian sintaktik kurang lebih adalah semacam "gramatika".

Semantika adalah cabang penyelidikan semiotika yang mempelajari hubungan diantara tanda-tanda dengan designata atau objek-objek yang diacunya. Yang dimaksud desegnata adalah makna tanda-tanda sebelum digunakan di dalam tuturan tertentu.

Pragmatika adalah cabang penyelidikan seemiotika yang mempelajari hubungan diantara tanda-tanda dengan intrepeter-intrepeter atau para pemakai tanda-tanda. Pragmatik secara khusus berurusan dengan aspek-aspek komunikasi, khususnya fungsi-fungsi situasional yang melatari tuturan. ${ }^{15}$

Dalam dunia semiotika, seperti yang diungkap ferdinand, bahasa dianggap sebagai "tanda" (sign) yang memiliki komponen signifiant dan signifie. Melakukan analisis tentang tanda orang harus tahu benar mana aspek material dan mana aspek mental. Kedua aspek ini merupakan aspek-aspek konstitutif suatu tanda, tanpa salah satu unsur ini tidak akan ada sebuah tanda dan kita tidak bisa membicarakannya, bahkan tidak bisa membayangkannya. ${ }^{16}$

Selain tanda, ada istilah lain yang seringkali dipersamakan, yaitu simbol. Robert Sibrani, dengan mengutip pendapat van Zoest; simbol adalah sesuatu yang dapat menyimbulkan dam mewakili ide, pikiran, perasaan, benda, dan tindakan secara arbitrer, konvensional dan representatif-interpretatif. Dalam hal ini, tidak ada hubungan alamiah antara yang menyimbolkan dan yang disimbolkan. Implikasinya berarti, baik yang batiniah (perasaan, pikiran atau

${ }^{15}$ Kris Budiman, semiotika Visual, (Yogyakarta: Buku baik, 2004), hlm. 5.

${ }^{16}$ St. Sunardi, membaca al-Qur'an Bersama Muhammad Arkoun, dalam tradisi, kemodernnan dan Metamodernisme: Memperbincangkan Pemikiran Muahammad Arkoun, ed. Johan Hendrik Meuleman, (Yogyakarta: LkiS, 1996), hlm.48. 
ide) maupun yang lahiriah ( benda dan tindikan) dapat diwakili dengan simbol. ${ }^{17}$

Sementara dalam konsep Pirce simbol diartikan sebagai tanda yang mengacu pada objek tertentu di luar tanda itu sendiri. Hubungan antara simbol sebagai penanda dengan sesuatu yang ditandakan (petanda) sifatnya konvensional. Berdasarkan konvensi itu pula masyarakat pemakainya menafsirkan ciri hubungan antara simbol dengan objek yang diacu dan menafsirkan maknanya. Dalam arti demikian, kata misalnya, merupakan salah bentuk simbol karena hubungan kata dengan dunia acuannya ditentukan berdasarkan kaidah kebahasaanya. Kaidah kebahasaannya itu secara artifisial ditentukan berdasarkan konvensi masyarakat pemakainya.

Dalam bahasa kominikasi, simbol sering diistilahkan sebagai lambang. Lambang sebenarnya juga adalah tanda. Hanya bedanya lambang tidak meberi tanda secara langsung, melainkan melalui sesuatu yang lain. Warna merah pada bendera sang merah putih merupakan lambang "keberanian", dan putih lambang "kesucian". Seperti kata Odgen dan Richard, lambang ini bersifat konvensional. Simbol atau lambang adalah sesuatu yang digunakan untuk menunjuk sesuatu lainya berdasarkan kelompok orang. Lambang meliputi kata-kata (pesan verbal), perilaku non-verbal, dan obyek yang maknanya disepakati bersama, misalnya memasang bendera di halaman rumah untuk menyatakan penghormatan atau kecintaan kepada negara.

Dari penjelasan di atas, simbol dan lambang merupakan salah satu ketegori tanda (sign). Sebagaimana dalam wawasan Pirce, bahwa tanda (sign) terdiri atas ikon (icon), indeks (index), dan simbol (symbol). Pada dasarnya ikon merupakan tanda yang bisa menggambarkan ciri utama sesuatu meskipun sesuatu yang lazim meskipuun disebut sebagai obyek acuan tersebut tidak hadir. Hubungan antara tanda dengan obyek dapat juga direpresentasikan oleh ikon dan indeks, namun ikon dan indeks tidak memerlukan kesepakatan. Kemudian, istilah simbol dalam pandangan Peirce lazim disebut kata (word),

17 Akhmad Muzakki, Kontribusi Semiotika Dalam Memahami Bahasa Agama ..., hlm. 14. 
nama (name), dan label (label). Sebab itu tidak mengherankan apabila pengertian tanda, simbol, maupun kata seringkali tumpang tindih. ${ }^{18}$

\section{Elemen Dasar Semiotika}

Charles Sanders Peirce, seorang ahli filsafat dari Amerika, mengatakan kita hanya dapat berpikir dengan sarana tanda. Sudah pasti bahwa tanpa tanda kita tidak dapat berkomunikasi. Dari sekian banyak pakar semiotika, ada dua orang yang patut disebutkan seecara khusus dalam hubungannya dengan kelahiran seemiotika moddern, yaitu charles Sanders peirce dan Ferdinand de Saussure. Peirce sebagai ahli filsafat dan logika lebih memusatkan perhatian pada pertannyaan "Bagaimana kita menalar?" sementara Saussure adalah seorah ahli lingguistik, pertanyaan yang mengganggunya adalah "Apakah sebenarnya bahasa itu?"

Pierce mengusulkan kata semiotika sebagai sinonim logika. Logika harus mempelajari bagaimana orang menalar. Berdasarkan hipotesis Pierce penalaran harus melalui tanda. Tanda memmungkinkan kita berfikir, berhubungan dengan orang lain, dan memberi makna pada apa yang ditampilkan oleh alam semesta. Salah satu bentuk tanda adalah kata, sedangkan obyek adalah sesuatu yang dirujuk tanda. Sementara interpretan adalah tanda yang ada dalam benak seseorang tantang obyek yang dirujuk sebuah tanda. Apabila ketiga elemen makna itu berinteraksi dalam benak seseorang, maka muncullah makna tentang sesuatu yang diwakili oleh tanda tersebut. ${ }^{19}$

Pembahasan mengenai elemen dasar semiotika ini mencakup tiga persoalan, yaitu; pertama, komponen tanda; kedua, relasi tanda, dan ketiga, tingkatan tanda. Dalam perkembangannya, semiotika menganut dikotomi bahasa yang dikembangkan Saussur, yaitu tanda (sign) memiliki hubungan antara penanda (significant/signifier) dan petanda (signifie/ signified).

\footnotetext{
${ }^{18}$ Alex Sobur, Analisiss Teksi Media: Suatu Pengantar Untuk Analsis Wacana, Analisis Semiotik, dan Analisis Framing, (Bandung: Remaja Rosdakarya, 2001), hlm. 159.

${ }^{19}$ Alex Sobur, Analisiss Teksi Media: Suatu Pengantar Untuk Analsis Wacana, Analisis Semiotik, dan Analisis Framing ..., hlm.109.
} 
Penanda adalah aspek material, seperti suara, huruf, bentuk,gambar dan gerak, sedangkan petanda adalah aspek mental atau konseptual yang ditunjuk oleh aspek material. Kedua aspek ini, yaitu penanda dan petanda kemudian disebut komponen tanda. Suara yang muncul dari sebuah kata yang diucapkan merupakan penanda, sedangkan koknsepnya adalah petanda. sehingga keberadaan dua unsur ini tidak bisa dipisahkan, dan pemisihan hanya menggaburkan pengertian kata (tanda) itu sendiri. Misalnya, buku, ini merupakan tanda yang terdiri dari unsur makna atau yang diartikan, dan unsur bunyi dalam wujud fonem $(b, u, k, u)$ yang mengartikan. Kemudian tanda "buku" mengacu pada satu referen yang berada di luar bahasa yang menjadi kesepakatan bersama.

Didalam konteks strukturalisme bahasa, tanda tidak dapat hanya dilihat secara individu, akan tetapi dalam relasi dan kombinasinya dengan tandatanda lainnya di dalam sebuah sistem. Analisis tanda berdasarkan sistem atau kombinasinya yang lebih besar ini melibatkan apa yang disebut aturan pengkombinasian, yang terdiri dari dua model relasi, yaitu relasi sintagmatik dan relasi paradigmatik.

Relasi sintagmatig adalah sebuah relasi yang merujuk kepada hubungan in praesentia diantara satu kata dengan kata-kata yang lain, atau antara satuan gramatikal dengan satuan gramatikal yang lain di dalam ujaran atau tindak tutur (speech act). Karena tuturan selalu diekpresikan sebagai suatu rangkaian tanda-tanda verbal dalam dimensi waktu, maka relasi sintagmatik kadang disebut juga relasi-relasi linear.

Relasi sintagmatik ini berkebalikan dengan relasi asosiatif, yang di dalam linguistik pasca Saussure disebut sebagai relasi paradigmatik. Di dalam relasi ini setiap tanda berada di dalam kodenya sebagai bagian dari suatu paradigma, suatu sistem relasi in absentia yang mengikatkan tanda-tanda tersebut dengan tanda-tanda lain sebelum ia muncul dalam tuturan. Dengan kata lain, relasi paradigmatik adalah cara pemilihan dan pengkombinasian 
tanda-tanda berdasarkan aturan atau kode tertentu, sehingga dapat menghasilkan sebuah ekpresi bermakna.

Roland Barthes mengembangkan dua tingkatan pertandaan yang memungkinkan untuk dihasilkannya makna yang juga bertingkat-tingkat, yaitu tingkat denotasi dan konotasi. Denotasi adalah tingkat pertandaan yang menjelaskan hubungan antara penanda dan petanda, atau antara tanda dan rujukannya pada realitas, yang menghasilkan makna ekplisit, langsung dan pasti. Makna denotasi dalam hal ini, adalah makna pada apa yang tampak. Misalnya, foto Ahmad, berarti wajah Ahmad yang sesungguhnya. Denotasi adalah tanda yang penandannya mempunyai tingkat konvensi atau kesepakatan yang tinggi.

Konotasi adalah tingkat pertandaan yang menjelaskan hubungan antara pananda dan petanda, yang di dalamnya beroperasi makna yang tidak ekplisit, tidak langsung dan tidak pasti (terbuka terhadap berbagai kemungkinan). Ia menciptakan makna-makna lapis kedua, yang terbentuk ketika penanda dikaitkan dengan berbagai aspek psikologis, seperti perasaan, emosi, atau keyakinan. Misalnya, tanda bunga, ia mengkonotasikan kasih sayang. Konotasi dapat menghasilkan makna lapis kedua yang bersifat implisit,tersembunyi, inilah yang disebut makna konotatif.

Jadi, denotasi makna yang paling nyata dari tanda, sedangkan konotasi adalah istilah yang menunjukkan signifikasi tahap kedua. Konotasi mempunyai makna yang subyektif atau paling tidak intersubyektif. Dengan kata lain, denotasi adalah apa yang digambarkan tanda terhadap obyek, sementara konotasi adalah bagaimana menggambatkan tanda tersebut. ${ }^{20}$

\section{Bahasa dan Pikiran}

Menurut Abdul Chaer, Berbahasa adalah penyampaian pikiran atau perasaaan dari orang yang berbicara mengenai masalah yang dihadapi dalam

\footnotetext{
${ }^{20}$ Akhmad Muzakki, Kontribusi Semiotika Dalam Memahami Bahasa Agama ..., hlm. 17-
} 23. 
kehidupan budayanya. Jadi, kita lihat berbahasa, berpikir, dan berbudaya adalah tiga hal atau tiga kegiatan yang saling berkaitan dalam kehidupan manusia Berbahasa, dalam arti berkomunikasi, dimulai dengan membuat enkode semantic dan encode gramatikal didalam otak pembicara, dilanjutkan dengan membuat encode fonologi. Kemudian di lanjutkan dengan penyusunan decode fonologi, decode gramatikal, dan decide semantic pada pihak pendengar yang terjadi di dalam otaknya. berikut ini pendapat beberapa pakar lingustik mengenai hubungan bahasa dan pikiran.

\section{Teori Wilhelm Von Humboldt}

Wilman helm Von Humboldt, sarjana jerman abad ke-19, menekankan adanya ketergantungan pemikir manusia pada bahasa. Maksudnya, pandangan hidup dan budaya masyarakat ditentukan oleh bahasa masyarakat itu sendiri. Anggota-anggota masyarakat itu tidak dapat menyimpang lagi dari garis-garis yang telah ditentukan oleh bahasanya itu. Kalau salah seorang dari anggota masyarakat ini ingin mengubah pandangan hidupnya, maka dia harus mempelajari dulu satu bahasa lain. Maka dengan demikian dia akan menganut cara berpikir (dan juga budaya) masyarakat bahasa lain. Mengetahui bahasa itu sendiri Von Humbolt berpendapat bahwa substansi bahasa itu terdiri dari dua bagian. Bagian pertama berupa bunyi-bunyi, dan bagian lainnya berupa pikiran-pikiran yang belum terbentuk. Bunyi-bunyi dibentuk oleh lautform, dan pikiran-pikiran dibentuk oleh ideeform atau innereform. Jadi, bahasa menurut Von Humboldt merupakan sintese dari bunyi (lautform) dan pikiran (ideeform).

Dari keterangan itu bisa disimpulkan bahwa bunyi bahasa merupakan bentuk-luar, sedangkan pikiran adalah bentuk-dalam. Bentuk-luar bahasa itulah yang kita dengar, sedangkan bentuk dalam-bahasa berada di dalam otak. Kedua bentuk inilah yang"membelenggu" manusia, dan menentukan cara berpikirnya. Dengan kata lain, Von Humboldt berpendapat bahwa struktur suatu bahasa menyatakan kehidupan dalam( otak, pemikir) penutur bahasa itu. 


\section{Teori L.S. Vygotsky}

Vygotsky, sarjana bangsa Rusia, berpendapat adanya satu tahap perkembangan bahasa sebelum adanya pikiran, dan adanya satu tahap perkembangan pikiran sebelum adanya bahasa. Kemudian, kedua garis perkembangan ini saling bertemu, maka terjadilah secara serentak pikiran berbahasa dan bahasa berpikir. Dengan kata lain, pikiran dan bahasa pada tahap permulaan berkembang secara terpisah, dan tidak saling mempengaruhi. Jadi, mula-mula pikian berkembang tanpa bahasa, dan bahasa mula-mula berkembang tanpa pikiran. Lalu pada tahap berikutnya, keduanya bertemu dan bekerja sama, serta saling mempengaruhi. Begitulah anak-anak berpikir dengan menggunakan bahasa dan berbahasa dengan menggunakan pikiran.

Menurut Vygotsky dalam mengkaji gerak pikiran ini kita harus mengkaji dua bagian ucapan dalam yang mempunyai arti yang merupakan aspek semantic ucapan, dan ucapan luar yang merupakan aspek fonetik atau aspek bunyi-ucapan. Penyatuan dua bagian atau aspek ini sangat rumit dan kompleks. Pikiran dan kata, menurut Vygotsky tidak dipotong dari satu pola. Struktur ucapan tidak hanya mencerminkan, tetapi juga mengubahnya setelah pikiran berubah menjadi ucapan.

\section{Teori Bruner}

Berkenaan dengan masalah hubungan bahasa dan pikiran, Bruner memperkenalkan teori yang disebutnya Teori Instrumentalisme. Menurut teori ini bahasa adalah alat pada manusia untuk mengembangkan dan menyempurnakan pemikir itu. Dengan kata lain, bahasa dapat membantu pikiran manusia supaya dapat berpikir lebih sistematis. Dalam bidang pendidikan, implikasi teori Bruner ini sangat besar. Memang dalam hubungan inilah beliau ingin mengembangkan teori ini.

Di samping adanya dua kecakapan yang melibatkan bahasa, yaitu kecakapan linguistic dan kecakapan komunikasi, teori Bruner ini juga memperkenalkan adanya kecakapan analisis yang dimiliki oleh setiap manusia 
yang berbahasa. Kecakapan analisis ini akan dapat berkembang menjadi lebih baik dengan pendidikan melalui bahasa yang formal karena kemampuan analisis ini hanya mungkin dikembangkan setelah seseorang mempunyai kecakapan komunikasi yang baik.

\section{Teori Jean Piaget}

Jean Piaget merupakan pakar yang berasal dari Perancis. Menurutnya, pikiranlah yang membentuk bahasa. Tanpa pikiran, bahasa tidak ada. Pikiranlah yang menentukan aspek-aspek sintaktis dan leksikon bahasa, bukan sebaliknya. Bahasa merupakan satu sistem kode yang sudah siap untuk digunakan yang diperluas dan dilengkapi oleh masyarakat penggunanya. Bahasa mengandung sejumlah kekayaan alat kognisi yang selalu siap digunakan. Dalam pemerolehan bahasa, seorang anak dapat menggolongkan sekumpulan benda dengan memakai kata-kata yang serupa dengan bendabenda tersebut. Hal ini berarti kognisinya dapat ditentukan. Jadi, perkembangan kognisinya mempengaruhi perkembangan bahasanya. ${ }^{21}$

\section{Kesimpulan}

Bahasa merupakan media berkomunikasi yang penuh dengan persoalan yang menuntut analisis yang berifat filosofis, misalnya, teori asal usul bahasa tidak lain hanya berdasar pada spekulatif, sehingga kebenarannya juga bersifat spekulatif. Bahasa, semiotika dan pikiran memiliki keterkaitan yang saling mempengaruhi (resiprokal). Dalam wacana lingguistik, bahasa diberi pengertian sebagai sistem simbol bunyi yang bermakna dan berartikulasi, yang dipakai sebagai alat komunikasi oleh sekelompok manusia untuk melahirkan perasaan dan pemikiran. Sedangkan dalam pengertian metaforis, istilah bahasa mengacu pada berbagai cara komunikasi atau berkontak (isyarat atau simbol lainnya). Adapun semiotika mempelajari sistem-sistem, aturan-aturan, yang pikiran.html

${ }^{21}$ https://linguistick-of-art.blogspot.com/2017/03/psikolinguistik-bahasa-dan- 
memungkinkan tanda-tanda tersebut mempunyai arti. Dengan kata lain, semiotika mempelajari relasi diantara komponen-komponen tanda, serta relasi antara komponen-komponen terseebut dengan masyarakat penggunanya. Adapun pikiran akan membuat enkode semantic dan encode gramatikal didalam otak pembicara, dilanjutkan dengan membuat encode fonologi. Kemudian di lanjutkan dengan penyusunan decode fonologi, decode gramatikal, dan decide semantic pada pihak pendengar yang terjadi di dalam otaknya sehingga komunikasi kedua belah pihak antara pembicara dan pendengar dapat saling mengerti dan memahami. 


\section{Daftar Pustaka}

Budiman, Kris, semiotika Visual. Yogyakarta: Buku baik. 2004.

Fachri, Asal Usul Bahasa, diakses dari http://fachri86.wordpress.com/2012/10/24/asal-usul-bahasa/ pada hari Rabu, 20 November 2019

Ghafur, Abd, Okara, jurnal bahasa dan sastra. Pamekasan: pusat bahasa STAIN. Vol.ii. Tahun 4, Nopember 2009.

Hidayat,Komaruddin Hidayat, Memahami Bahasa Agama. Jakarta: Paramadina. 1996.

Muzakki, Akhmad, Kontribusi Semiotika dalam Memahami Bahasa Agama. Malang: UIN Malang Press. 2007.

Pei, The History of langguage, alih bahasa, Nugroho Notosusanto. Jakarta: Bratara. 1965.

Satria, Huubungan Bahasa, Berfikir dan Berbudaya, diakses dari http:/ / satria87-satria87.blogspot.com/2010/03/hubungan-berbahasaberpikir-dan.html diakses pada hari kamis 20 November 2019

Saussure, Ferdinand de, Cours de Linguistique generale, alih bahasa, Harimurti kridalaksana, pengantar Linguistik umum. Yogyakarta: Gadjah Mada Univeersity Press. Cet, 3. 1996.

Sobur, Alex, Analisis Teks Media: Suatu Pengantar Untuk Analisis Wacana, Analisis Semiotik, dan Analisis Framing. Bandung: Rosda Karya. 2001.

St. Sunardi, membaca al-Qur'an Bersama Muhammad Arkoun, dalam tradisi, kemodernnan dan Metamodernisme: Memperbincangkan Pemikiran Muahammad Arkoun, ed. Johan Hendrik Meuleman. Yogyakarta: LkiS. 1996. 